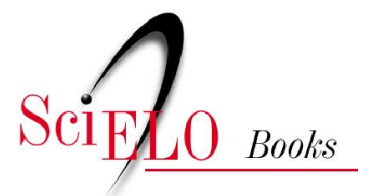

\title{
Avança, Brasil
}

\author{
Fernando Henrique Cardoso
}

CARDOSO, FH. Avança, Brasil: proposta de governo [online]. Rio de Janeiro: Centro Edelstein de Pesquisas Sociais, 2008. pp. 160-161. Avança, Brasil. ISBN: 978-85-99662-68-7. Available from SciELO Books $<\underline{\text { http://books.scielo.org }>\text {. }}$

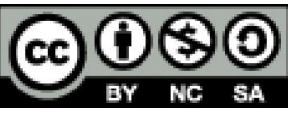

All the contents of this chapter, except where otherwise noted, is licensed under a Creative Commons Attribution-Non Commercial-ShareAlike 3.0 Unported.

Todo o conteúdo deste capítulo, exceto quando houver ressalva, é publicado sob a licença Creative Commons Atribuição Uso Não Comercial - Partilha nos Mesmos Termos 3.0 Não adaptada.

Todo el contenido de este capítulo, excepto donde se indique lo contrario, está bajo licencia de la licencia Creative Commons Reconocimento-NoComercial-CompartirIgual 3.0 Unported. 


\section{AVANÇA, BRASIL}

Muito foi feito, porém é preciso fazer mais.

Esse enunciado, que aparece em numerosas passagens deste programa de governo, não é um recurso retórico. Ao contrário, a expressão traduz, talvez com mais exatidão do que quaisquer outras palavras, o sentido essencial, o ponto de partida e o horizonte dos compromissos contidos neste documento.

Ao pedir aos brasileiros que lhe concedam um segundo mandato, o presidente Fernando Henrique - ao mesmo tempo em que se orgulha do longo caminho de realizações percorrido nestes quatro anos, das dificuldades vencidas e das energias que a própria caminhada fez despertar em todo o país - é o primeiro a afirmar, com a mesma ênfase, que todas as vitórias alcançadas na luta contra o atraso e a injustiça social ainda são por demais insuficientes perto do que a esmagadora maioria da população reclama, a justo título, em matéria de trabalho, educação, saúde, qualidade de vida e cidadania. Para si e para as gerações que irão continuar a construir no novo século um país também novo.

Esse reconhecimento manifesta, antes de tudo, o respeito à verdade dos fatos, com o qual o presidente Fernando Henrique jamais transigiu por palavras ou ações. Em segundo lugar, não é de hoje que ele acredita - ao contrário da retórica de seus adversários e mais até do que eles próprios na singela e profunda lição aprendida em décadas de convívio com o povo, com gente de todas as condições, origens sociais e inclinações políticas: a lição de que, felizmente, foi-se o tempo em que era possível ganhar uma eleição, sobretudo nacional, subestimando a inteligência do eleitor. Doutor ou apenas capaz de desenhar o nome, o brasileiro sabe o quanto há por fazer para virar definitivamente as pesadas páginas do passado.

Por fim, ao estabelecer esse elo entre as realizações - a começar do triunfo sobre a inflação - e os novos compromissos - a começar da luta contra o desemprego -, o presidente Fernando Henrique e o conjunto de forças sociais e políticas que apóiam a sua candidatura reiteram a certeza de que a obra nova só se erguerá como prosseguimento, aperfeiçoado sempre, corrigido onde for preciso, da trajetória cumprida desde o primeiro dia de 1995. E não como rupturas aventureiras ou saltos no escuro, os quais, tenham o nome que lhes queiram dar seus desavisados proponentes, significam inevitavelmente uma coisa apenas: retrocesso.

Fazer mais, olhando sempre para o mesmo objetivo - a transformação radical e duradoura das condições de vida dos brasileiros mais pobres e mais vulneráveis - é, sim, dar continuidade ao trabalho já realizado. Mas é também avançar. Isso é tão mais necessário quanto mais se percebe, dia após dia, o poder devastador, para a vida de nações, governos, sistemas produtivos e populações inteiras, das crises que percorrem o planeta.

Nesta fase em que instituições antigas de toda ordem se desmancham; em que tardam a nascer aquelas verdadeiramente capazes de dar estabilidade à produção de riquezas, aos grandes avanços da ciência e da tecnologia e ao desenvolvimento sustentado da civilização humana, a capacidade das lideranças nacionais em promover o progresso com justiça, integração e defesa do ambiente se mede pela nitidez de sua visão dos rumos a seguir e de sua aptidão em propor, encaminhar e levar a cabo programas coerentes com essa visão, articulados entre si e, por isso mesmo, eficazes.

Essa visão se expressa nas idéias reunidas neste programa de governo, que propõe um projeto novo para o Brasil. A firmeza na condução deste projeto, em um mundo em crise e marcado pela incerteza, exige capacidade permanente de perceber as mudanças, e disposição e competência para promover um amplo diálogo com todas as forças da sociedade e articulá-las numa vigorosa aliança pelo desenvolvimento com eqüidade.

No Brasil de 1998, o atual governo sabe com certeza para onde ir, tem o domínio dos meios 
necessários, a percepção atenta dos problemas e a prontidão de resposta para enfrentá-los impedindo a todo custo que venham a anular as conquistas, hoje patrimônio da nação inteira, ou se antepor ao duradouro crescimento da economia, do emprego e da renda. E se tem tudo isso é porque o contagiam, desde a primeira hora, a extraordinária confiança dos brasileiros em seu futuro, a garra e a alegria, quem sabe únicas no mundo assim unidas, que fazem o povo acreditar - mais do que isso, saber - que a vitória é certa. 